\title{
Factors Affecting Consumer Behavior in Purchasing Home Furnishing Products in Bangladesh
}

\author{
Nishat Nigar \\ Lecturer, Department of Marketing, Comilla University, Cumilla-3506, Bangladesh
}

Received: 06 Feb 2021; Received in revised form: 03 Apr 2021; Accepted: 03 May 2021; Available online: 22 May 2021

\begin{abstract}
Home furnishing products are not the frequently purchased item that's why majority people in Bangladesh are more conscious about selecting and taking final decision to purchase furniture. The decision of purchasing furniture is affected by several factors like store aesthetic design, customer consciousness, brand, reference, convenience and price. The degree of importance of these factors is also exaggerated by demographic variables of consumers considering family size, income and educational qualification. The purpose of the study is to examine how different factors plays significant roles behind purchase intention of furniture among the people in Bangladesh. To conduct this research purposive random sampling technique was used to yield a sample size of 230 people in Bangladesh. Statistical Package for the Social Science (SPSS) version 22 is used as data analysis method. The outcome of the analysis reveals that, consumers decision making process in purchasing home furnishing items is affected severely by the mentioned factors though they are aware regarding those factors. So, marketers of furniture industry can build a strong competitive position for their companies by emphasizing on those factors because consumers in Bangladesh significantly aware about those.
\end{abstract}

Keywords-Consumer Behavior, Home Furnishing Products, Store Aesthetic Design, Customer Consciousness, Brand, Reference, Convenience, Price, Bangladesh.

\section{INTRODUCTION}

In today's competitive market, though there are so many factors that affect consumer behavior, simultaneously sellers are also more conscious about their buyer and the factors that affect their purchasing behavior. Furniture is the most indispensible household items from essentials to fashionables. In Bangladesh people normally choose durable, comfortable and easy to maintainable as well as fashionable furniture. There are different people from different socio-economic levels who respond to the factors that affect purchasing behavior of household items differently. Though there are different options in the hand of customer both local and national level brands are available, customer normally o some pre-purchase search, that's why sellers have to understand from top to toe of customers purchasing behavior. Consumer behavior is difficult to predict though consumer plays different roles buyer, payer and user, who will finally buy seller have to understand and make them buy (Gajjar, N. B., 2013). Household furnishing items reveals the choice and social status of people and the degree of self satisfaction and comfort.

Though there are very few research focused on purchasing behavior of household furniture and on pre purchase search factors but there is no way of negligence that for everyone home is the place of peace if it is well decorated and comfortable there may not have any argument. The characteristics of consumer buying behavior may vary with the nature of market competition exists in the industry which ultimately affect the bargaining power (Porter, M. E.,2011). Consumers are more conscious about the material quality specially the wood quality and the finishing of design even if the traditional design is not a matter of fact in Bangladesh. Though most of the people in Bangladesh are middle income group they focus on durability and they belief that wood is the top material which is most durable. They want to pass more than a decade with furniture and think there is huge cost involved in the replacement of furniture. Purchasing behavior of consumers from semi-urban and rural area is different from those of urban area in Bangladesh. Income level, 
social status, self identity and other demographic indicators may affect purchasing behavior of people in Bangladesh. Brand image works more in purchasing behavior of urban people whereas rural people are more conscious about durability, price and material especially wooden furniture they prefer most. Sellers who offer best quality, comfort, after sales service, repairing service, good material can achieve the faith of customers and satisfied customer do word-of-mouth promotional activity on the basis of their past good experience.

In Bangladesh many people like to make furniture from the trees they grown in their land, they think it is cheaper, quality is assured and satisfaction level is higher. Many people like to purchase furniture from fair though it is less costly and they feel joyous to purchase from a fair that is normally observed once in a year. Urban people most of the time depend on either local level brand or national level, they gather information, analyze information and finally make purchasing decision. Leather, plastic, oak wood and metal furniture have also become popular in some sense and same as in case of imported furniture all over the country. The furniture at home is self expletory regarding lifestyle and identity of people that's why they are too much engaged on information search regarding many factors before purchase (Ponder, N., 2013).Furniture purchasing decisions depends on some factors and those factors also influenced by demographic profile in some extent. The study is undertaken to find out the factors and their degree of influence in furniture purchasing decisions. Few researches have been conducted on the consumer behavior towards purchasing household furniture in Bangladesh perspective before. Delivery time is related with demand, if there is a change in delivery time ranges 2-7 days demand may be reduced by 37.5 percent in furniture market (Marino, G., Zotteri, G., \& Montagna, F., 2018). Mashao, E. T., \& Sukdeo, N. , (2018) argued that the influencing factors like product features, price, market reputation, advertising and experience are analyzed by customer before purchasing long lasting household goods. Different age group and monthly income per household influence furniture purchase where three important factors are material, price and service (Oblak, L., Glavonjić, B., Barčić, A. P., Govedič, T. B., \& Grošelj, P., 2020). Environmental awareness, health consciousness are significant elements which are responsible for purchasing green furniture (Khojasteh-Khosro, S., Shalbafan, A., \& Thoemen, H., 2020). Furniture industry always face newer pace of competition in attracting and keeping customers. Finding those factors that a customer evaluate before purchasing furniture is a matter of research that's why the study was undertaken and reveal new ways to the furniture marketers in designing marketing strategies. The study is aimed at finding those factors that are considered during furniture purchasing process by the people in Bangladesh. There are some emerging issues considered in this study which are overlooked in previous study.

The objectives of the study intend finding the factors which works behind the purchasing behavior of household furniture comparing to their demographic information of Bangladeshi people in recent years in this competitive market and the degree of importance of those factors.

\section{LITERATURE REVIEW AND HYPOTHESES}

Review on the study of consumer behavior in Home Furnishing Products is limited though this chapter reveals the meaning of Social Factors, Consumer Behavior and Home Furnishing Products. Prior this study, some significant factors like sensitivity, durability, uniqueness, customization, finishing quality, innovative design, wood quality and influence of media (expression of self image) have influence on Furniture purchasing (Nayeema A., Husna A., 2015). There is positive and significan relationship among reference group, family, quality, price, color and purchasing decision factors and these are the greatest indicator of behavioral intension (Al-Azzam, A. F M., 2016). Some other factors like damaged furniture, new furniture for new residence, new form are considered when purchasing a new furniture (Sakpichaisakul, T. (2012).

Various dimensions on merchandizing display such as window display, store layout, store front, creative display, shelf display, trend and coordination have impact on consumer behavior in furniture market (Mehta, N., \& Chugan, P. K., 2015). Store image and Customer lifestyle have profound impact on customer patronage in furniture market (Hassan, Y., Muhammad, N. M. N., \&Bakar, H. A., 2010). Physical health concern and past experience are positively associated with customer's intention to purchase green furniture whereas attitude and perceived behavioral control have no significant association in purchase intention (Xu, X., Hua, Y., Wang, S., \&Xu, G., 2020). Before buying furniture customer undertake some prepurchase search such as role, cost, durability of furniture which has connection with customer characteristics (Mona Kamal Ismail, 2010).People prefer to purchase home furnishings in festival, marriage and renovation time (Ruhil, A., Yadav, N., \& Arya, N., 2017).

There is a positive and significant relationship between Purchasing decision, Social factors like- family, social status, role, reference group; product attributes likequality, price, design, color; lifestyle is identified (Duong Thi Hanh Phuong, 2016). Also, there may possibly eight factors that have influence on making choice or selecting furniture, those are: ease of maintenance, comfort, price, style, quality, color, material and matching with other 
items (Yoon and Cho, 2009). Consumer purchasing decision of furniture mostly depends on short delivery time (Marino, G., Zotteri, G. and Montagna, F., 2018). People having difficulty in purchasing costly furniture can avail if stores provide them Equal Monthly Installment (EMI) facilities. Store decoration has critical role in consumer's intention to purchase (Yaoqi Li, Hui Fu, Songshan (Sam) Huang , 2015). Purchasing furniture from store which are next to the door minimize time, cost and effort, even there may work personal relationship. Customers are fascinated by new design, which are uncommon and avoid obsolete one. Furniture those are on sale people don't want to lose that chance and grab it. Discounted price format is less effective than fixe price because it shows less perceived value and quality. Higher price indicates higher quality but it varies from product to product (Gerstner, E., 1985). Customer's interaction with salespersons increased due to their support on products information and reviews from varieties (Mallalieu, L., 2006).

\subsection{Factors that affect Consumer in purchasing furniture \\ Brand image}

Brand can differentiate an organization's product and service from those of other organization. The role of a brand in an organization is condemnatory as it makes higher margin and loyal customers for the organization (Philip Kotlar, Brand Management, and Marketing Management). Branded furniture indicates higher quality and performance. Brand indicated some unique features of furniture and customers are normally eager to pay higher price for purchasing branded furniture. Brand image management is a process which includes selecting, introducing, elaborating and stimulating brand concept sequentially (Park, C. W., Jaworski, B. J., \& Mac Innis, D. J., 1986). Brand equity can be exploited by providing specific brand relations that's create image and attitude towards brand equity (Faircloth, J. B., Capella, L. M., \& Alford, B. L., 2001). Product features specially technology and design associated with Brand (Adidam, P. T., Mallela, J., \& Eesley, D. T., 2016).

\section{Equal Monthly Installment (EMI) Facility}

EMI or equated monthly installment, every part is equally divided charged monthly basis settlefull outstanding loan within expiry (The Economics Time). EMI is one of the payment method which helps customer to purchase products by paying a lamp-sum down payment and the rest amount in monthly basis. Many non-bank financial institutions now promote and make available their consumer durables or non durables in the competitive market by introducing EMI facility at $0 \%$ interest rate, Non-bank financial organizations use EMI to serve its customers in retail market by understanding their problem
(Gadre, M., \& Soni, S., 2019).People having problem in paying whole payment at a time while purchasing furniture can be benefited by EMI facility.

\section{Store display}

Store display is the most useful promotional tool (Kinley, T. R., \& Brandon, L., 2015). Store display can attract customer to the most attractive piece (Moore, C., 2006). Vertical display of furniture can broaden the warehouse and minimize the store length and customer can enjoy this furniture display cart (Farlow, C. B. 1990). A miniature display kit can be helpful in promotional activity so that customer can take a look in brief (Nelson, S. D., \& Underwood, D. M., 2016). The arrangement the furniture store display should be on group basis where each group consists similar items that ultimately help customers to choose according to their lifestyle (Thompson, D., 2005). Store display with perfect arrangement and attractive decoration can easily attract customer and lead them to take purchasing decision (Suri, R., Manchanda, R. V., \&Kohli, C. S.,2000). Different extent of display like: store display, window display, store front, store environment, store layout and co-ordination have impact on the consumer's purchasing behavior. It is important for the sellers to differentiate themselves in this regard store display become an important tool for them (Mehta, N., \& Chugan, P. K., 2014).

\section{Furniture design and material}

Furniture design rely on people's choices like how they sit, rest, work which are influenced by cultural, political, and societal conditions (Postell, J., 2012). A good design is a unquestioned determinant in attracting the customers and build a good experience of quality and uses (Bloch, P. H., 1995). Consumer prefer lightweight furniture which are made of wood-based-panels with sub-criteria like design, price, quality and guarantee even with a bit more price (Khojasteh-Khosro, S., Shalbafan, A., \& Thoemen, H., 2020). Wood is the most popular form of material of furniture though it reveals several finer attributes compared to other raw materials and also wood is good looking and trendy and finding a substitutes of it is difficult to achieve (Pakarinen, T., 1999). Wood is the most preferred furniture compared to others which influence customers in of interior and exterior furniture purchasing decisions (Kaputa, V., Barčić, A. P., Mat'ová, H., \& Motik, D., 2018).

\section{Price}

Price is the most sensitive factor of purchasing behavior among consumers in Bangladesh. Price is the sign of quality, consumer decision process is affected by pricing strategy (Gijsbrechts, E., 1993). Some consumer suffers from price discrimination bias (Haucap, J., \& Heimeshoff, U., 2011). The persuasion of price fairness increase 
customer's target to purchase but it has also some adverse effect like negative-word of-mouth activity, switching the seller etc. (Malc, D., Mumel, D., \& Pisnik, A., 2016). There is a positive relation among price fairness, trust, satisfaction and buying intension (Konuk, F. A., 2018). Consumers are price sensitive in nature but higher price dictates higher quality. Intense competition in the market leads consumers to be more sensible towards loss and less sensible towards gains (Han, S., Gupta, S., \& Lehmann, D. R., 2001).

\section{Quality and comfort}

Quality and comfort these two are parallel concept. Furniture which is made of quality materials is usually comfortable. Comfort is related with quality perception and which ultimately leads to satisfaction (Rodriguez, M. C., Ooms, A., \& Montañez, M., 2008). Loyal customers are comfortable with the quality service and they became satisfied (Ribbink, D., Van Riel, A. C., Liljander, V., \& Streukens, S., 2004). People even ready to pay a bit higher price for getting a comfortable furniture.

\section{Demographic Factors}

Demographic factors like disposable income, age are most spontaneous buying indicator whereas educational qualification, gender are marginal indicator of buying behavior (Bashar, A., Ahmad, I., \& Wasiq, M., 2013). Family size, marital status, income, gender, number of children influence purchasing behavior of households (Abdullahi Farah, A., Zainalabidin, M., \& Ismail, A. L., 2011). Income and educational qualification significantly and directly related with impulse buying behavior simultaneously age and gender also affect the same (Awan, A. G., \& Abbas, N., 2015). Consumer behavior is not a static phenomenon it is ever changing with the change of demographic factors like- age, sex, family size, income, geographic factors, psychographic factors (Kumar, R., 2014). The review of the product uses, brand preferences, buying habits, the way of gathering information are closely tied with demographic profiles (Juyal, S. A., 2013). Five demographic factors such asage, gender, family size, income and education are considered as the influencers of consumer responses to sales promotions (Vipul, P., 2010). Consumer behavior and degree of involvement to a particular product category are significantly influenced by income level, age, culture and effective marketing strategy is designed on the basis of market segmentation which is based on demographic factors (Yousaf, S., \& Huaibin, L., 2013).

Table 1: Hypotheses Statements Table

\begin{tabular}{|l|}
\hline Hypotheses Statements \\
\hline $\begin{array}{l}\text { H1: There is positive relationship between furniture design } \\
\text { and Consumer's furniture purchasing decision }\end{array}$ \\
\hline
\end{tabular}

H2: There is positive relationship between store aesthetic design and Consumer's furniture purchasing decision

H3: There is positive relationship between customer's consciousness and Consumer's purchasing decision

H4: There is positive relationship between promotional factors and Consumer's purchasing decision

H5: There is positive relationship between brand and Consumer's furniture purchasing decision

H6: There is positive relationship between reference influence and Consumer's purchasing decision

H7: There is positive relationship between convenient furniture and Consumer's purchasing decision

H8: There is positive relationship between Price and Consumer's purchasing decision

\section{METHODOLOGY}

To serve the purpose of the study, the researcher selects a criterion in order to select participants as respondents. The criterion is that, participant must have the experience of purchasing furniture for household purpose. The researcher used digital self-administered questionnaire to collect data. Physically it was difficult to collect data due to lockdowns and social distancing regulations due to covid-19 pandemic. The study is undertaken in Bangladesh covering several divisions. 230 respondents provided useable data to carry out the study. There are Eight factors considered in the integrated model i.e. furniture design, store aesthetic design, consciousness, promotional factors, brand, reference influence, convenience and price.

The main source of secondary data is related articles, websites, books from which literature review is prepared. Structured questionnaire having 3 parts containing 54 items is prepared for data collection where part-1 represents demographic variables such as gender, age, educational qualification, occupation, marital status, family size, family income, residential area. Part-2 contains 25 items regarding consumer's furniture purchasing behavioral intention where respondents have given their opinion as five point Likert Scales were used. Part-3 consists 21 items regarding the degree of importance of the factors that matches the respondent's opinion. Primary data is collected from 230 respondents by applying convenience and purposive sampling technique. The purposive or judgmental sampling is used because of the objective of the study. Participants who have furniture purchasing experience are selected as respondents. Pre-test for the questionnaire items on target population was conducted to evaluate the reality and validity of the survey. The questionnaire items are picked from existing literature and target population is pre tested

This article can be downloaded from here: www.ijaems.com 
on the basis of their past experience of furniture purchase. Several statistical tools like mean, median, standard deviation and regression analysis are applied to analyze the data which are collected through questionnaire by using SPSS.

\section{THEORETICAL FRAMEWORK}

Identifying of factors that affect consumer's behavior has a numerable consideration in previous research. Theory of anticipated behavior model is selected as basic theoretical framework which includes variables based on survey data where perceived behavior control consumer's purpose to purchase furniture (Xu, X., Hua, Y., Wang, S., \& Xu, G., 2020). Philip Nelson (1970) argued that, if there are limitations in the knowledge and information about quality, consumers are continuously making choices among alternatives which ultimately affect purchasing decisions. The research study consider Brand image ((Park, Jaworski, \& MacInnis, 1986, Faircloth, Capella, \& Alford, 2001, Adidam, Mallela, \& Eesley, 2016), Equal
Monthly Installment (EMI) facility (Gadre, M., \& Soni, S., 2019), store display (Kinley, Brandon, 2015, Moore, 2006, Farlow, 1990, Nelson, Underwood, 2016, Thompson, 2005, Suri, Manchanda, \& Kohli, 2000, Mehta, Chugan, 2014), furniture design and material (Postell, 2012, Bloch, 1995, Khojasteh-Khosro, Shalbafan, \& Thoemen, 2020, Pakarinen, 1999, Kaputa, Barčić, Mat’ová, \& Motik, D., 2018), Price (Gijsbrechts, 1993, Haucap, Heimeshoff, 2011, Malc, Mumel, \& Pisnik, 2016, Konuk, 2018, Han, Gupta, \& Lehmann, 2001), quality and comfort (Rodriguez, Ooms, \& Montañez, 2008, Ribbink, Van Riel, Liljander, \& Streukens, 2004) are considered as dependent variables. Customer's demographic factors (age, income, family size, educational qualification, profession) are also considered dependent variables in this research study. On the other side, Consumer's purchasing decision (AlAzzam, 2016, Sakpichaisakul, 2012, Mehta, Chugan, 2015, Xu, X., Hua, Y., Wang, \& Xu, G. 2020, Ruhil, Yadav, \& Arya, 2017), is considered as independent variable in this research study.

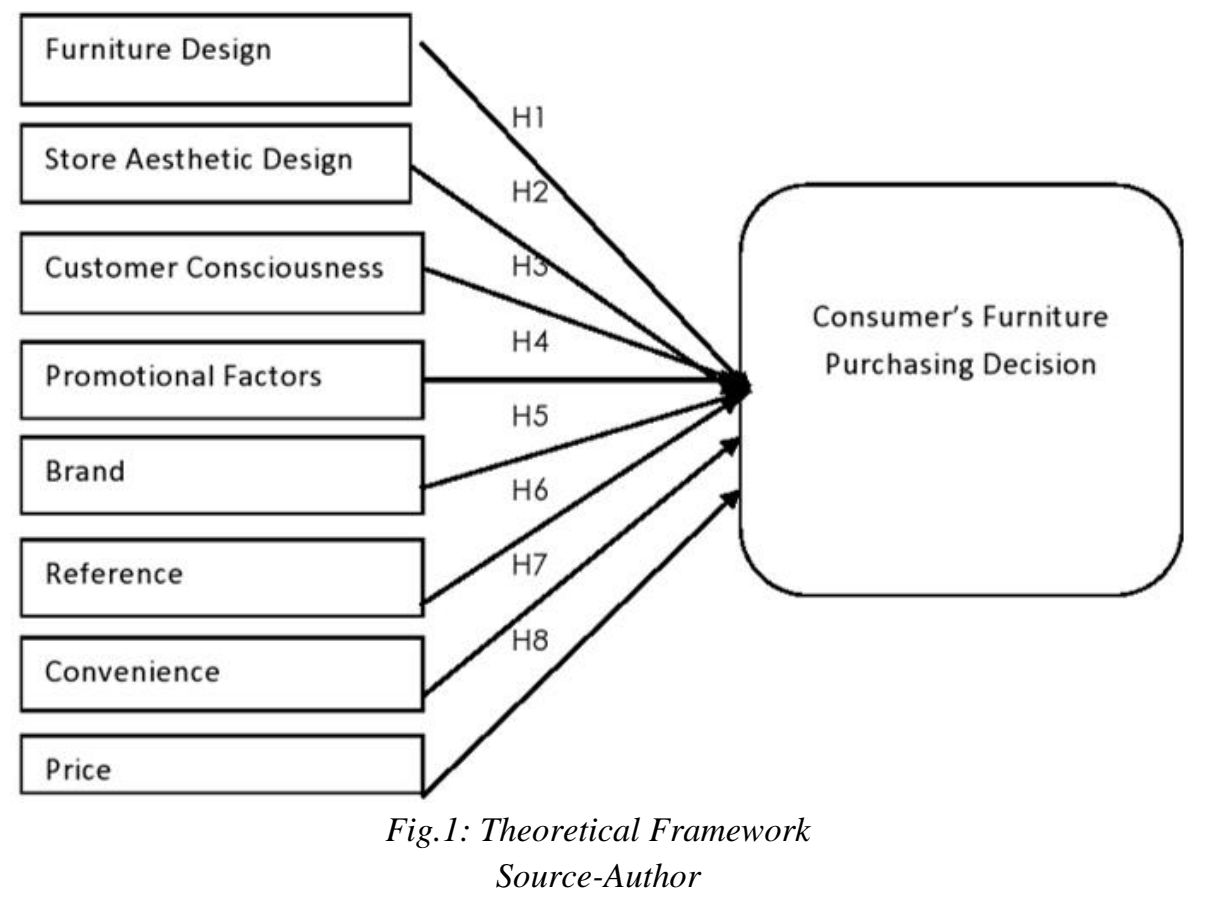

\section{RESULTS AND DISCUSSION}

\subsection{Demographic profile of the respondent}

The various frequencies and percentages of the demographic profiles of respondents are shown in Table 2. Most of the Respondents are males (61.7\%) while $38.3 \%$ are females. It is noted that respondents are predominantly of age range 31-40 years old. With respect to educational qualification, $69.6 \%$ of respondents are post graduates, $19.6 \%$ of respondents are graduates, and it indicates that educated people are more conscious about different variables that affect their purchasing behavior. In case of occupation, most of the respondents are service holder (64.3\% are service holder. $53 \%$ respondents are belong to the family having 3-4 members and $29.6 \%$ belong to family having 5-6 members. While considering income, $27.4 \%$ respondents are from 590 \$- 825 \$ monthly income group and $26.1 \%$ from 355 \$ -590 \$ monthly income group. Highest number of respondents are from urban locality $(75.2 \%)$ while second highest from semi urban (18.3\%). 
Table 2: Demographic Profile

\begin{tabular}{|c|c|c|}
\hline Variables & Frequency & Percentage \\
\hline \multicolumn{3}{|l|}{ Gender } \\
\hline Male & 142 & 61.7 \\
\hline Female & 88 & 38.3 \\
\hline \multicolumn{3}{|l|}{ Age } \\
\hline $21-30$ years & 60 & 26.1 \\
\hline $31-40$ years & 128 & 55.7 \\
\hline $41-50$ years & 32 & 13.9 \\
\hline $51-60$ years & 10 & 4.3 \\
\hline \multicolumn{3}{|l|}{ Educational Qualification } \\
\hline Below than Secondary School & 2 & 0.9 \\
\hline Secondary School Certificate (SSC) & 5 & 2.2 \\
\hline Higher Secondary Certificate (HSC) & 8 & 3.5 \\
\hline Under Graduate & 8 & 3.5 \\
\hline Graduate & 45 & 19.6 \\
\hline Post Graduate & 160 & 69.6 \\
\hline $\mathrm{PhD}$ & 2 & 0.9 \\
\hline \multicolumn{3}{|l|}{ Occupation } \\
\hline Student & 5 & 2.2 \\
\hline Service Holder & 148 & 64.3 \\
\hline Self-employed & 27 & 11.7 \\
\hline Housewife & 28 & 12.2 \\
\hline Retired & 5 & 2.2 \\
\hline Unemployed & 3 & 1.3 \\
\hline Others & 14 & 6.1 \\
\hline \multicolumn{3}{|l|}{ Marital Status } \\
\hline Single & 29 & 12.6 \\
\hline Married & 201 & 87.4 \\
\hline \multicolumn{3}{|l|}{ Family Size } \\
\hline $1-2$ & 23 & 10.0 \\
\hline $3-4$ & 122 & 53.0 \\
\hline $5-6$ & 68 & 29.6 \\
\hline $7-8$ & 11 & 4.8 \\
\hline More than 8 & 6 & 2.6 \\
\hline \multicolumn{3}{|l|}{ Family Income (Monthly) } \\
\hline Less than $120 \$$ & 3 & 1.3 \\
\hline $121 \$-355 \$$ & 22 & 9.6 \\
\hline $356 \$-590 \$$ & 60 & 26.1 \\
\hline $591 \$-825 \$$ & 63 & 27.4 \\
\hline $826 \$-1065 \$$ & 30 & 13.0 \\
\hline More than $1065 \$$ & 52 & 22.6 \\
\hline \multicolumn{3}{|l|}{ Residential Area } \\
\hline Urban & 173 & 75.2 \\
\hline Semi Urban & 42 & 18.3 \\
\hline Rural & 15 & 6.5 \\
\hline
\end{tabular}

\subsection{Consumers furniture purchasing behavior}

A complete picture of different factors that influence consumer furniture purchase behavior is shown in Table 3 by expressing opinion of respondents on different issues

This article can be downloaded from here: www.ijaems.com related to knowledge formation. Most respondents agreed that customer consciousness $(\mathrm{M}=4.398533 \quad \&$ $\mathrm{SD}=0.652577$ ) are the most relevant factors in the perception of consumers furniture purchasing behavior. 
The second concern is Convenience $(\mathrm{M}=4.01955$ \& $\mathrm{SD}=$ $0.69808)$ which are most important that affect furniture market positively. Brand $(\mathrm{M}=3.930467 \& \mathrm{SD}=0.748473)$ is the third critical element. The fourth one is Price $(\mathrm{M}=3.7913 \quad \& \quad \mathrm{SD}=0.87164) . \quad$ Furniture design $(\mathrm{M}=3.545675$ \& $\mathrm{SD}=0.904985)$ is fifth, Store Aesthetic
Design $(\mathrm{M}=3.370675 \& \mathrm{SD}=1.08948)$ is sixth, Reference $(\mathrm{M}=3.15 \& \mathrm{SD}=0.91865)$ is seventh important variables. Whereas, promotional factors $(\mathrm{M}=2.827533$ \& $\mathrm{SD}=1.049063)$ are the least important that influence consumer's purchasing behavior as per the respondents opinion.

Table 3 Descriptive Statistics Analysis

Descriptive Statistics

\begin{tabular}{|c|c|c|c|}
\hline Variable & Mean & Std. Deviation & $\mathbf{N}$ \\
\hline \multicolumn{4}{|l|}{ Furniture Design } \\
\hline 1. Innovative Design & 3.8957 & 0.74616 & 230 \\
\hline 2. New Furniture Model & 3.7913 & 0.78184 & 230 \\
\hline 3. Nearest Furniture Store & 2.8435 & 1.10253 & 230 \\
\hline 4. Matching with other furniture & 3.6522 & 0.98941 & 230 \\
\hline Average & 3.545675 & 0.904985 & \\
\hline \multicolumn{4}{|l|}{ Store Aesthetic Design } \\
\hline 1. Vertical arrangement in furniture store & 3.2957 & 1.06942 & 230 \\
\hline 2. Creative shelf display and layout & 3.5217 & 1.10456 & 230 \\
\hline 3. EMI facility on furniture store & 3.3696 & 1.17764 & 230 \\
\hline 4. Positive store image & 3.2957 & 1.00630 & 230 \\
\hline Average & 3.370675 & 1.08948 & \\
\hline \multicolumn{4}{|l|}{ Customer Consciousness } \\
\hline 1. Role, cost, durability of furniture & 4.4565 & 0.65772 & 230 \\
\hline 2. Physical health issues & 4.2348 & 0.70346 & 230 \\
\hline 3. Adjustable with lifestyle & 4.5043 & 0.59655 & 230 \\
\hline Average & 4.398533 & 0.652577 & \\
\hline \multicolumn{4}{|l|}{ Promotional Factors } \\
\hline $\begin{array}{l}\text { 1. Salesperson's influence on furniture selection } \\
\text { process }\end{array}$ & 2.6652 & 1.06394 & 230 \\
\hline 2. Furniture on sale & 2.2217 & 1.06080 & 230 \\
\hline 3. Discounted furniture & 3.5957 & 1.02245 & 230 \\
\hline Average & 2.827533 & 1.049063 & \\
\hline \multicolumn{4}{|l|}{ Brand } \\
\hline 1. Purchasing branded furniture is easier task & 3.8609 & 0.87555 & 230 \\
\hline 2. Branded furniture built with unique feature & 3.9696 & 0.72022 & 230 \\
\hline 3. $\quad$ Brand assured quality & 3.9609 & 0.64965 & 230 \\
\hline Average & 3.930467 & 0.748473 & \\
\hline \multicolumn{4}{|l|}{ Reference influence } \\
\hline 1. Reference group influence in furniture purchase & 3.4174 & 0.86648 & 230 \\
\hline 2. Social media influence & 2.8826 & 0.97082 & 230 \\
\hline Average & 3.15 & 0.91865 & \\
\hline \multicolumn{4}{|l|}{ Convenient furniture } \\
\hline 1. Comfortable Furniture & 4.4043 & 0.67841 & 230 \\
\hline 2. Easy to maintainable furniture & 4.2217 & 0.69838 & 230 \\
\hline 3. Timely delivery service & 3.8739 & 0.70353 & 230 \\
\hline 4. $\quad$ Environmental factors & 3.5783 & 0.71200 & 230 \\
\hline Average & 4.01955 & 0.69808 & \\
\hline \multicolumn{4}{|l|}{ Price } \\
\hline 1. Quality dictates price & 3.7913 & 0.87164 & 230 \\
\hline Furniture purchasing decision & & & \\
\hline
\end{tabular}

This article can be downloaded from here: www.ijaems.com 
Table 4 shows that correlation coefficient value $(R)$ is 0.478 that indicates there is a moderate positive relationship between consumer's furniture purchasing decisions and furniture design, store aesthetic design, customer consciousness, promotional factors, brand, reference influence, convenient furniture, price. Furthermore, Just 22.9 percent (R-square values of 0.229) of the difference in consumer's furniture decisions is accounted for furniture design, store aesthetic design, customer consciousness, promotional factors, brand, reference influence, convenient furniture, and price. The author's finding also represents the degree of relevance of influencing factors with the demographic factors in addition to the findings from the previous studies. This gap will contribute to the existing literature.

Table 4 Model Summary

\begin{tabular}{|c|c|c|c|c|c|c|c|c|c|}
\hline \multirow[b]{2}{*}{ Model } & \multirow[b]{2}{*}{ F } & \multirow[b]{2}{*}{ R Square } & \multirow[b]{2}{*}{$\begin{array}{l}\text { Adjusted } \\
\text { R Square }\end{array}$} & \multirow[b]{2}{*}{$\begin{array}{l}\text { Std. Error of } \\
\text { the Estimate }\end{array}$} & \multicolumn{5}{|c|}{ Change Statistics } \\
\hline & & & & & $\begin{array}{l}\text { R Square } \\
\text { Change }\end{array}$ & F Change & df1 & df 2 & $\begin{array}{c}\text { Sig. F } \\
\text { Change }\end{array}$ \\
\hline 1 & $.478^{\mathrm{a}}$ & .229 & .201 & .67516 & .229 & 8.186 & 8 & 221 & .000 \\
\hline
\end{tabular}

Source: Researcher field data

\subsection{Confirm the model fitness}

Table 5 represents that multiple regression analysis is conducted to analyze the relationship between consumer's furniture purchasing decisions and furniture design, store aesthetic design, customer consciousness, promotional factors, brand, reference influence, convenient furniture, price. Eight hypotheses are suggested and the conclusions are enumerated in Table 3. The F-statistics is 8.186 ( $\mathrm{F}=$ 8.186) and significance level is 0.000 which is less than 0.01 and for regression analysis the model fitness is assured.

Table 5 ANOVA $^{a}$

\begin{tabular}{|ll|r|r|r|r|r|}
\hline Model & & Sum of Squares & Df & Mean Square & F & Sig. \\
\hline 1 & Regression & 29.851 & 8 & 3.731 & 8.186 & $.000^{\mathrm{b}}$ \\
& Residual & 100.740 & 221 & .456 & & \\
& Total & 130.591 & 229 & & & \\
\hline
\end{tabular}

Source: Researcher field study

\subsection{Factors influencing consumer's furniture purchasing decisions}

The findings of multiple regression analysis for $\mathrm{H} 2$ is described in Table 6 as store aesthetic design, which influences Consumers' furniture purchasing decisions significantly and positively $(\beta 2=0.038 ; \mathrm{t}$-value $=0.604 ; \mathrm{p}$ $>0.05)$. H2 is accepted. Therefore, store aesthetic design has influence on customer's furniture purchasing decisions. People are attracted by store design because they can easily find out their desired one from a planned shelf rather than a messy one. H3 substantiates that customer consciousness has positive and substantial impact on consumer's furniture purchasing decisions ( $\beta 3=$ $0.194 ;$ t-value $=2.864 ; \mathrm{p}>0.05)$. H3 is accepted. Customer consciousness has effect on consumer's furniture purchasing decision. Consciousness regarding health issues, environmental impact has enormous effects on furniture purchasing decisions. H5 presents Brand as a critical factor which positively and considerably influence consumer's furniture purchasing decision $(\beta 5=0.064$; $t$ - value $=0.971 ; \mathrm{p}>0.05) . \mathrm{H} 5$ is accepted. People generally feel proud and get satisfied for using or getting owner of a furniture of well known and famous brand. Then, H6 refers reference influence which is a major factor that has positively and noticeably impact on consumer's furniture purchasing decision $(\beta 6=0.174 ; \mathrm{t}$-value $=2.763 ; \mathrm{p}<0.05)$. So, H6 is accepted. Reference group have a powerful position in Bangladeshi people's mind. Before purchasing furniture they normally search information and try to get opinion regarding final selection. Furthermore, H7 is described as convenient furniture which is another crucial factor that influence consumer's furniture purchasing decision positively and extensively $(\beta 7=0.166$; $\mathrm{t}$-value $=$ 2.510; $\mathrm{p}<0.05)$. H7 is accepted. Furniture which is easy to maintain, easy to carry significantly attract people in Bangladesh. Next, H8 specifies price which is a critical factor that positively and notably influence consumer's furniture purchasing decision $(\beta 8=0.103$; $\mathrm{t}$-value $=1.602$; p> 0.05). H8 is accepted. Price is an important and sensitive factor for people from a developing country like 
Bangladesh. Due to price factor low-medium income group have to compromise many other factors.

The results in Table 6 confirm $\mathrm{H} 1$ as furniture design, which influences Consumers' furniture purchasing decisions negatively and insignificantly $(\beta 1=-0.146 ; \mathrm{T}=$ -2.226; $\mathrm{p}<0.05)$. H1 is not accepted. Then, H4 specify promotional factor influence consumers furniture purchasing decision negatively and insignificantly $(\beta 4=-$ $0.122 ; \mathrm{t}$-value $=-1.880 ; \mathrm{p}>0.05)$. So, $\mathrm{H} 4$ is not accepted. It is assured that furniture design and promotional factor has no impact on consumer's furniture purchasing decision.

Table 6 Coefficients

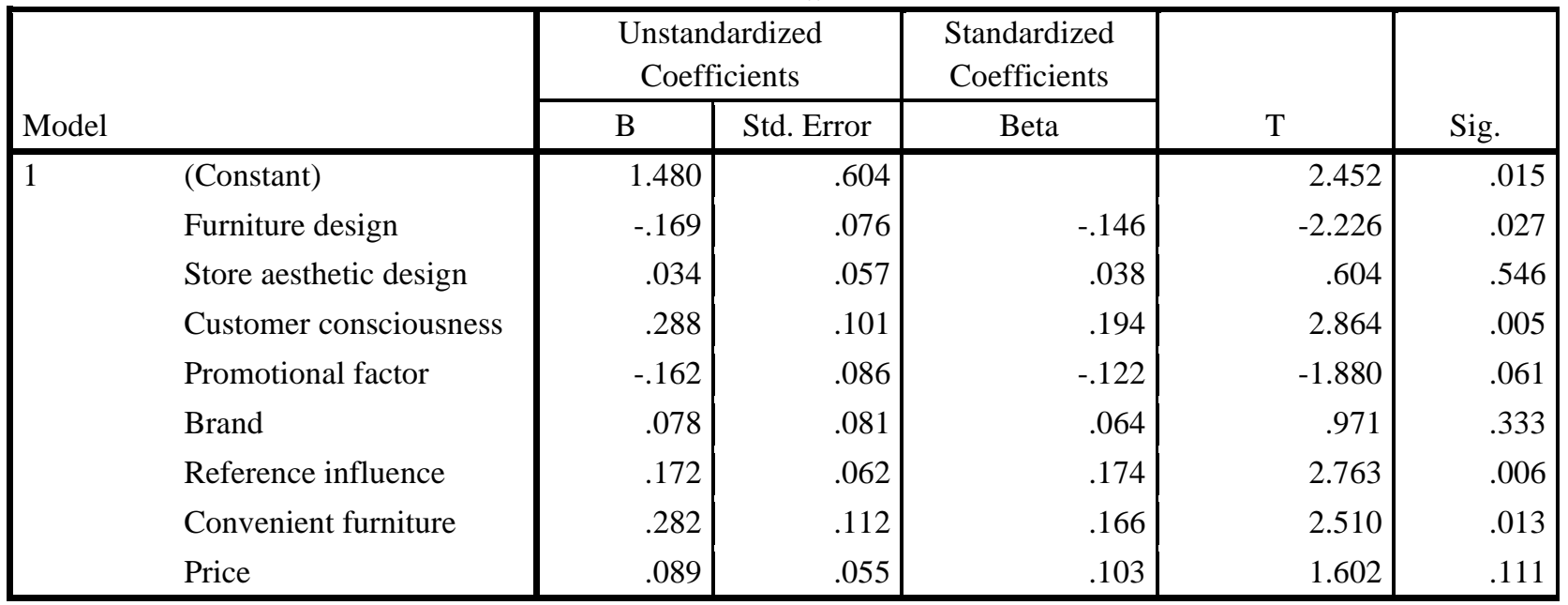

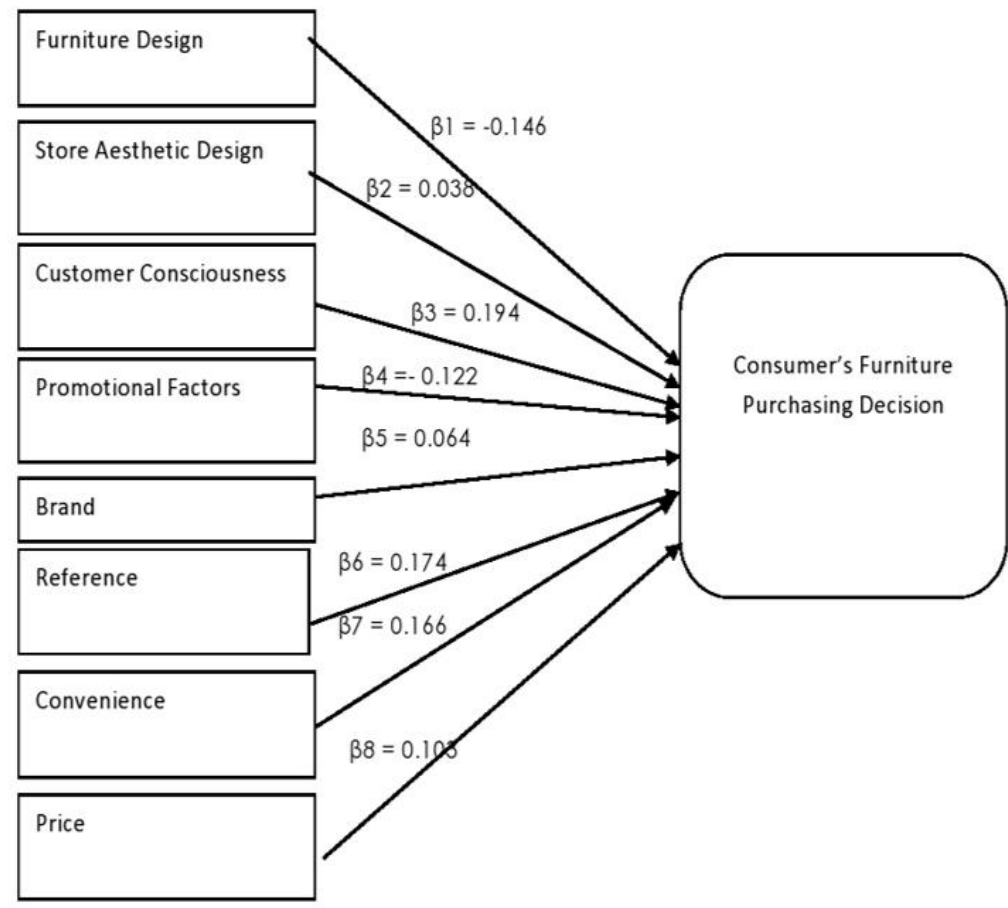

Fig.2: The outcome of the full model

\section{CONCLUSION AND IMPLICATIONS}

The study has been initiated with the objective to analyze different factors that persuade consumer's decision making process of purchasing furniture that may highlight on consumer behavior towards furniture purchase. The research has been conducted on Bangladesh perspective. The outcome may vary depending on geographic changes.
The findings of the study represents several factors such as store aesthetic design, customer consciousness, brand, reference, convenient furniture and price have positive and significant persuasion on consumer behavior towards furniture purchasing decision and also the degree of importance of those factors depend on demographic profile of the respondents. To carry on the study, primary data has

This article can be downloaded from here: www.ijaems.com 
been collected through structured questionnaire from different areas inside Bangladesh. Literature review has been developed from numerous sources of secondary data. Convenient and judgmental sampling was used in this survey. From regression analysis, the degree of significance between the influencing factors and consumer's decision making process has been revealed.

The study found many factors that are considered in furniture purchasing decision in Bangladesh. The findings are based on the data provided by 230 respondents from different area within Bangladesh. Some of the factors are considered in previous research in Bangladesh perspective. Some are considered beyond Bangladesh. The researcher had tried to accumulate all those factors that are considered from Bangladesh perspective.

The main implication of this study is for the marketers of furniture industry. They could be benefited by the outcomes of this research which helps them to restructure their marketing strategies for furniture market to build more competitive position in the industry. Marketers can segment their markets based on demographic profiles of customers by following the factors that influence the purchasing decisions. Actually, what consumers want; which factors they mostly consider while purchasing furniture could be better understood from the insights of this study. On the other hand, the outcome of this research could be beneficial for the future researchers, who want to conduct research on this sector and want to find out more weighty factors that may affect consumer's behavior towards furniture purchasing decision.

\section{LIMITATION OF THE STUDY AND FURTHER RESEARCH}

The results of this research is applicable for Bangladesh only, probably the outcome has little help for other countries perspective. The outcome may not present whole Bangladeshi peoples view because of the sample size. Further analysis is recommended by expanding the sample size in other areas of the country. There may have some overlooked factors that have crucial impact on consumer's behavior towards furniture purchasing decision that could be addressed in further research.

\section{REFFERENCES}

[1] Gajjar, N. B. (2013). Factors affecting consumer behavior. International Journal of Research in Humanities and Social Sciences, 1(2), 10-15.

[2] Porter, Michael E. Competitive advantage of nations: creating and sustaining superior performance. simon and schuster, 2011. Consumer behavior, retailer power and market performance in consumer goods industries. The Review of Economics and Statistics, 419-436.
[3] Marino, G., Zotteri, G., \& Montagna, F. (2018). Consumer sensitivity to delivery lead time: a furniture retail case. International Journal of Physical Distribution \& Logistics Management.

[4] Mashao, E. T., \& Sukdeo, N. (2018). Factors that influence consumer behavior in the purchase of durable household products. In Proceedings of the International Conference on Industrial Engineering and Operations Management (pp. 26-27).

[5] Oblak, L., Glavonjić, B., Barčić, A. P., Govedič, T. B., \& Grošelj, P. (2020). Preferences of Different Target Groups of Consumers in Case of Furniture Purchase. Wood Industry/Drvna Industrija, 71(1).

[6] Khojasteh-Khosro, S., Shalbafan, A., \& Thoemen, H. (2020). Consumer behavior assessment regarding lightweight furniture as an environmentally-friendly product. Wood Material Science \& Engineering, 1-10.

[7] Ponder, N. (2013). Consumer attitudes and buying behavior for home furniture. Report prepared for the Furniture Outreach Program at Franklin Furniture Institute, Starkville, Mississippi, USA.

[8] Nayeema Ahmed, HusnaAra (2015), Factors influencing Household Consumers Preferrence for Wooden Furniture of Manufacturer Brands: A study on Bangladesh, The Jahangirnagar Journal of Business Studies Vol. 5, No. 1.

[9] Al-Azzam, A. F. M. (2016). The impact of customer relationship management on hotels performance in Jordan. International Journal of Business and Social Science, 7(4), 200- 210.

[10] SAKPICHAISAKUL, T. (2012). Consumer Behavior in Purchasing Home Furnishing products in Thailand. Graduate School of Commerce Waseda University.

[11] Mehta, N., \& Chugan, P. K. (2015). Visual Merchandising and Purchasing Behavior for High Involvement Products: A Study of Electronics Outlets. International Journal of Logistics \& Supply Chain Management Perspectives, 4(2), 1634-1654.

[12] Hassan, Y., Muhammad, N. M. N., \&Bakar, H. A. (2010). Influence of shopping orientation and store image on patronage of furniture store. International Journal of Marketing Studies, 2(1), 175.

[13] Xu, X., Hua, Y., Wang, S., \&Xu, G. (2020). Determinants of consumer's intention to purchase authentic green furniture. Resources, Conservation and Recycling, 156, $104721 .$.

[14] Ismail, M. K. (2010). Consumer shopping behavior for household furniture. International Journal of Arts and Sciences, 3(7), 342-359.

[15] Ruhil, A., Yadav, N., \& Arya, N. (2017). An Empirical Study on Consumers Buying Behaviour Towards Home Furnishings. Indian Journal of Economics and Development, 13(2), 345-352.

[16] Khuong, P. M. N, (2016), The Effects of Social Factors on Consumers Purchase Decision in Wooden Furniture Sector in Ho Chi Minh City, Vietnam.

[17] Yoon, S. Y., \& Cho, J. Y. (2009, March). Understanding furniture decision making process and design preference 
using web-based VR technology. In Annual Conference of IDEC, St. Louis, Missouri, March (pp. 25-28).

[18] Marino, G., Zotteri, G., \&Montagna, F. (2018). Consumer sensitivity to delivery lead time: a furniture retail case. International Journal of Physical Distribution \& Logistics Management.

[19] Li, Y., Fu, H., \& Huang, S. S. (2015). Does conspicuous decoration style influence customer's intention to purchase? The moderating effect of CSR practices. International Journal of Hospitality Management, 51, 19-29.

[20] Philip Kotler, Kevin Lane Kellar, Marketing Management

[21] Park, C. W., Jaworski, B. J., \&MacInnis, D. J. (1986). Strategic brand concept-image management. Journal of marketing, 50(4), 135-145.

[22] Faircloth, J. B., Capella, L. M., \& Alford, B. L. (2001). The effect of brand attitude and brand image on brand equity. Journal of marketing theory and practice, 9(3), 6175.

[23] Kinley, T. R., \& Brandon, L. (2015). Branding strategies for home furnishings products: Consumer perceptions. Journal of Marketing Development and Competitiveness, 9(1), 93.

[24] Adidam, P. T., Mallela, J., \&Eesley, D. T. (2016) Culture, Brand-Personality Congruence, And Product Features: Impact On Consumer's Preference. NATIONAL SOCIAL SCIENCE, 1.

[25] Moore, C. (2006). U.S. Patent Application No. 10/999,484.

[26] Postell, J. (2012). Furniture design. John Wiley \& Sons.

[27] Farlow, C. B. (1990). U.S. Patent No. 4,895,381. Washington, DC: U.S. Patent and Trademark Office.

[28] Nelson, S. D., \& Underwood, D. M. (2016). U.S. Patent No. 9,277,813. Washington, DC: U.S. Patent and Trademark Office.

[29] Thompson, D. (2005). U.S. Patent Application No. $10 / 772,775$.

[30] Bloch, P. H. (1995). Seeking the ideal form: Product design and consumer response. Journal of marketing, 59(3), 16-29.

[31] Suri, R., Manchanda, R. V., \&Kohli, C. S. (2000). Brand evaluations: a comparison of fixed price and discounted price offers. Journal of Product \& Brand Management.

[32] Gerstner, E. (1985). Do higher prices signal higher quality?. Journal of marketing research, 22(2), 209-215.

[33] Mallalieu, L. (2006). Consumer perception of salesperson influence strategies: an examination of the influence of consumer goals. Journal of Consumer Behaviour: An International Research Review, 5(3), 257-268.

[34] Gadre, M., \&Soni, S. (2019). A study on "consumer awareness towards promotion of Bajaj Finservemi scheme in retail market". ZENITH International Journal of Multidisciplinary Research, 9(5), 328-340.

[35] The

Times,https://economictimes.indiatimes.com/Category/E conomy/EMI defined

[36] Khojasteh-Khosro, S., Shalbafan, A., \&Thoemen, H. (2020). Consumer behavior assessment regarding lightweight furniture as an environmentally-friendly product. Wood Material Science \& Engineering, 1-10.
[37] Mehta, N., \&Chugan, P. K. (2014). Impact of visual merchandising on consumer behavior: A study of furniture outlets. Universal Journal of Management, Horizon Research Publishing Corporation, Alhambra, CA, USA, 2(6), 207-217.

[38] Mehta, N., \&Chugan, P. K. (2014). Impact of visual merchandising on consumer behavior: A study of furniture outlets. Universal Journal of Management, Horizon Research Publishing Corporation, Alhambra, CA, USA, 2(6), 207-217.

[39] Pakarinen, T. (1999). Success Factors of Wood as a Furniture Material. Forest Products Journal, 49(9).

[40] Kaputa, V., Barčić, A. P., Mat’ová, H., \&Motik, D. (2018). Consumer preferences for wooden furniture in Croatia and Slovakia. BioResources, 13(3), 6280-6299.

[41] Gijsbrechts, E. (1993). Prices and pricing research in consumer marketing: Some recent developments. International journal of research in marketing, 10(2), 115-151.

[42] Haucap, J., \& Heimeshoff, U. (2011). Consumer behavior towards on-net/off-net price

[43] differentiation. Telecommunications Policy, 35(4), 325332.

[44] Malc, D., Mumel, D., \&Pisnik, A. (2016). Exploring price fairness perceptions and their influence on consumer behavior. Journal of Business Research, 69(9), 3693-3697.

[45] Konuk, F. A. (2018). Price fairness, satisfaction, and trust as antecedents of purchase intentions towards organic food. Journal of Consumer Behaviour, 17(2), 141-148.

[46] Han, S., Gupta, S., \& Lehmann, D. R. (2001). Consumer price sensitivity and price thresholds. Journal of retailing, 77(4), 435-456.

[47] Rodriguez, M. C., Ooms, A., \&Montañez, M. (2008). Students' perceptions of online-learning quality given comfort, motivation, satisfaction, and experience. Journal of interactive online learning, 7(2), 105-125.

[48] Ribbink, D., Van Riel, A. C., Liljander, V., \&Streukens, S. (2004). Comfort your online customer: quality, trust and loyalty on the internet. Managing Service Quality: An International Journal.

[49] USC Libraries, University of Southern California, libguides.usc.edu

[50] Xu, X., Hua, Y., Wang, S., \&Xu, G. (2020). Determinants of consumer's intention to purchase authentic green furniture. Resources, Conservation and Recycling, 156, 104721 .

[51] Nelson, P. (1970). Information and consumer behavior. Journal of political economy, 78(2), 311-329.

[52] Bashar, A., Ahmad, I., \&Wasiq, M. (2013). A study of influence of demographic factors on consumer impulse buying behavior. Journal of Management Research, 13(3), 145-154.

[53] Abdullahi Farah, A., Zainalabidin, M., \& Ismail, A. L. (2011). The influence of socio-demographic factors and product attributes on attitudes toward purchasing special rice among Malaysian consumers. International Food Research Journal, 18(3). 
[54] Awan, A. G., \& Abbas, N. (2015). Impact of demographic factors on impulse buying behavior of consumers in Multan-Pakistan. European Journal of Business and Management, 7(22), 96-105.

[55] Kumar, R. (2014). Impact of Demographic Factors on Consumer Behaviour-A Consumer Behaviour Survey in Himachal Pradesh. Global Journal of Enterprise Information System, 6(2).

[56] Juyal, S. A. (2013). Effect of demographic factors on consumer buying behaviour of durable goods. Indian Journal of Marketing, 43(12), 24-33.

[57] Vipul, P. (2010). Impact of demographic factors on consumer response to sales promotions: an empirical study. Advances in Management.

[58] Yousaf, S., \& Huaibin, L. (2013). Profiling consumer behavior in the context of involvement level and demographic factors: evidence of within-country differences from a developing economy. Journal of Global Marketing, 26(1), 1-17. 